Review

\title{
Silicon Nitride, a Close to Ideal Ceramic Material for Medical Application
}

\author{
Robert B. Heimann
}

Am Stadtpark 2A, D-02826 Görlitz, Germany; robert.heimann@ocean-gate.de; Tel.: +49-3581-667851

\begin{abstract}
This topical review describes the salient results of recent research on silicon nitride, a ceramic material with unique properties. The outcome of this ongoing research strongly encourages the use of monolithic silicon nitride and coatings as contemporary and future biomaterial for a variety of medical applications. Crystallographic structure, the synthesis and processing of monolithic structures and coatings, as well as examples of their medical applications that relate to spinal, orthopedic and dental implants, bone grafts and scaffolds, platforms for intelligent synthetic neural circuits, antibacterial and antiviral particles and coatings, optical biosensors, and nano-photonic waveguides for sophisticated medical diagnostic devices are all covered in the research reviewed herein. The examples provided convincingly show that silicon nitride is destined to become a leader to replace titanium and other entrenched biomaterials in many fields of medicine.
\end{abstract}

Keywords: silicon nitride; structure; properties; processing; coatings; spinal implants; arthroplastic implants; bone scaffolds; dental implants; neural circuits; biosensors; medical diagnostics

Citation: Heimann, R.B. Silicon

Nitride, a Close to Ideal Ceramic Material for Medical Application. Ceramics 2021, 4, 208-223. https://doi.org/10.3390/ ceramics 4020016

Academic Editors: Stuart Hampshire and Gilbert Fantozzi

Received: 26 March 2021

Accepted: 28 April 2021

Published: 4 May 2021

Publisher's Note: MDPI stays neutral with regard to jurisdictional claims in published maps and institutional affiliations.

Copyright: (C) 2021 by the author. Licensee MDPI, Basel, Switzerland. This article is an open access article distributed under the terms and conditions of the Creative Commons Attribution (CC BY) license (https:// creativecommons.org/licenses/by/ $4.0 /)$.

\section{Introduction}

Today, the research and development of metallic, ceramic, polymeric and composite biomaterials have progressed to a high level of involvement and sophistication. This is related to the fact that an ever-increasing part of the world population is in need of the repair or replacement of dysfunctional or damaged parts of the body, such as dental roots and teeth, alveolar ridge augmentation, intraocular lenses, heart pacemakers, cochlear implants, and hip and knee endoprostheses [1]. As these biomaterials are supposed to be functioning in close contact with biological tissues, they have to be biologically safe, mechanically resilient, economically viable, and physiologically and esthetically acceptable. Biomaterials are expected to continue to provide a substantial economic impact on modern medicine as the parts of prosthetic devices in orthopedic, dental, cardiovascular, ophthalmological, and reconstructive surgeries, including their use as scaffolds for tissue engineering, surgical sutures, and drug and gene delivery vehicles [1].

Bioceramics come in two flavors: bioinert and bioactive. Typical bioinert ceramics in clinical use today are aluminum oxide, partially stabilized zirconium oxide and pyrolytic carbon, whereas bioactive ceramics include a range of calcium phosphates and surface-active bioglasses. Bioinert ceramics are copiously used in applications that require mechanically strong and resilient wear- and corrosion-resistant materials with excellent tribological properties, for example as femur heads and the acetabular cups of hip endoprostheses but also as intervertebral parts, in knee arthroplasty, and as dental root implants. These properties have made aluminum oxide, zirconium oxide, titanium dioxide, silicon nitride, pyrolytic graphite and diamond-like carbon important contenders for parts of load-carrying implants [2]. However, the inherent brittleness of ceramics and their finite capability to integrate with tissues restrict their clinical application at present.

Bioactive ceramics including hydroxylapatite, tri- and tetracalcium phosphates and bioglasses are predominantly utilized on account of their osseointegrative and in combination with tissue growth-supporting non-collagenous proteins and glycosaminoglycanes, 
osseoinductive properties that involve the recruitment of immature stem cells and the stimulation of these cells to develop into pre-osteoblasts. While hydroxylapatite is mainly used as an osseoconductive, i.e., bone-growth supporting coating [3] for hip and dental root implants that promote the attachment of osteoblasts to the surface and throughout the interior of scaffolds or implants, bioresorbable tricalcium phosphate finds application as filler materials for bone cavities and bone replacement material, whereas tetracalcium phosphate is used in dental and bone cements. Today, bioactive ceramics are applied increasingly together with polymers as hybrid nanocomposites designed to mimic salient properties of natural biomaterials.

Recently, increasing interest has been devoted to silicon nitride, an advanced ceramic material that excels by high compressive and flexural strengths, comparatively high fracture toughness, very low friction coefficient, strong corrosion resistance, improved medical imaging ability based on radiolucency in the visible and near-infrared region, enhanced biocompatibility and osseoconductivity, antimicrobial activity, and microengineering capability conducive to integrate electronics and mechanics together with computational, chemical and optical elements. Owing to these properties, silicon nitride is now emerging as a novel and promising bioceramic material for a multitude of medical applications. These applications include wear-resistant bearings for hip- and knee endoprosthetic implants, novel dental implants, spinal intervertebral spacers, tissue engineering scaffolds, antibacterial and antiviral coatings, wave guides for medical diagnostics, microtubes for intelligent neural circuits, micro-spectroscopic imaging devices, photonic ICs, optical biosensors, and others. As an additional bonus, most recently silicon nitride has been found to be a powerful solid-state bioceramic deactivator of single-stranded RNA (ssRNA) viruses including the SARS-CoV-2 virus [4]. Developments are underway to commercialize antimicrobial 'catch-and-kill' face masks comprising silicon nitride-coated polypropylene fibers to protect against the COVID-19 pandemic [5]. In light of all these beneficial properties, silicon nitride may be correctly considered as close to ideal bioceramics.

\section{Crystallographic Structure of Silicon Nitride}

Silicon nitride occurs in three polymorphic structures, two hexagonal $\alpha$ - and $\beta-\mathrm{Si}_{3} \mathrm{~N}_{4}$ modifications and a cubic $\left(\gamma-\mathrm{Si}_{3} \mathrm{~N}_{4}\right)$ high-pressure/high temperature modification with spinel structure.

As shown in Figure 1, the structures of hexagonal silicon nitride consist of somewhat distorted $\mathrm{SiN}_{4}$ tetrahedra that, by sharing corners, form distorted hexagonal rings arranged in layers with $\mathrm{ABCD} \ldots$ stacking sequence $\left(\alpha-\mathrm{Si}_{3} \mathrm{~N}_{4}\right)$ and $\mathrm{ABAB} \ldots$ stacking sequence $\left(\beta-\mathrm{Si}_{3} \mathrm{~N}_{4}\right)$.

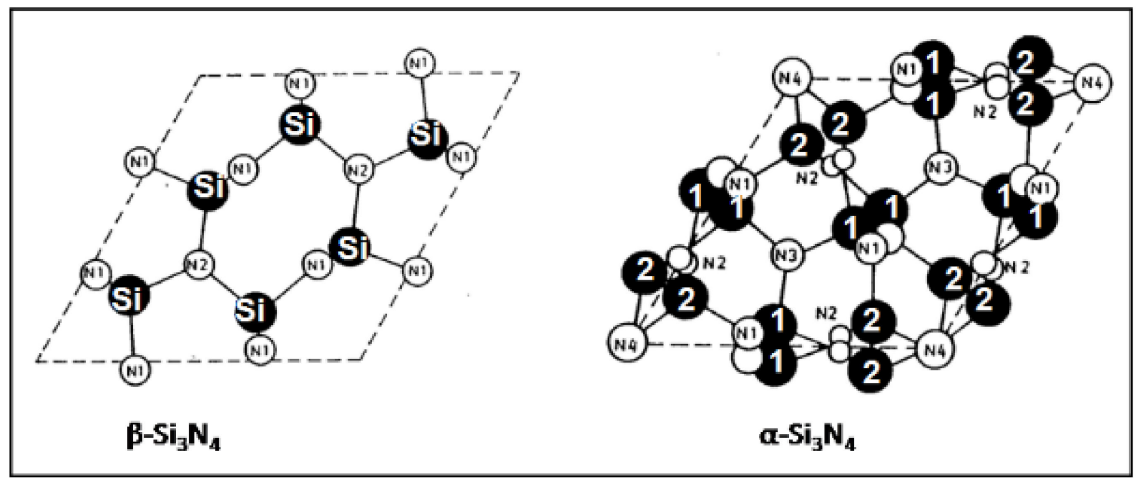

Figure 1. Arrangement of $\mathrm{Si}$ and $\mathrm{N}$ atoms in hexagonal $\beta$ - and $\alpha$-silicon nitride shown projected down the $\mathrm{c}$ axis onto the $\mathrm{AB}$ plane [6]. (C) With permission from Wiley-VCH.

Although the basic $A B$ layer is identical in both $\alpha$ - and $\beta$-phases, in the $\alpha$-phase, the second (CD) layer is related to the first (AB) layer by a c-glide plane. Since the double layer in $\alpha-\mathrm{Si}_{3} \mathrm{~N}_{4}$ can be considered a superposition of a $\beta-\mathrm{Si}_{3} \mathrm{~N}_{4}$ layer and its opposite 
inverted by $180^{\circ}$, there are twice as many atoms per unit cell in $\alpha-\mathrm{Si}_{3} \mathrm{~N}_{4}(Z=4)$ compared to $\beta-\mathrm{Si}_{3} \mathrm{~N}_{4}(Z=2)$. The interconnected $\mathrm{SiN}_{4}$ tetrahedra in $\beta-\mathrm{Si}_{3} \mathrm{~N}_{4}$ form wide channels that allow for enhanced ion diffusion throughout the lattice that assist in easy sintering at elevated temperatures. Consequently, the fabrication of dense biomedical parts should advantageously commence with $\beta-\mathrm{Si}_{3} \mathrm{~N}_{4}$ precursor powders [6].

\section{Synthesis and Processing}

\subsection{Synthesis and Properties of Monolithic Silicon Nitride Ceramics}

The mechanical, elastic, and thermal properties of structural variants of silicon nitride differ remarkably as shown in Table 1. Different synthesis routes of silicon nitride structures are shown in Figure 2.

Table 1. Selected mechanical and thermophysical properties of RBSN and SSN $[7,8]$.

\begin{tabular}{ccc}
\hline Property & RBSN & SSN \\
\hline Density $\left(\mathrm{Mg} \cdot \mathrm{m}^{-3}\right)(\%$ of theoretical density) & $70-88$ & $95-100$ \\
\hline Compressive strength $(\mathrm{MPa})$ & 600 & 2950 \\
\hline Flexural strength $\left(4-\right.$ point, $\left.25^{\circ} \mathrm{C}\right)(\mathrm{MPa})$ & $150-350$ & $500-1000$ \\
\hline Fracture toughness $\left(25^{\circ} \mathrm{C}\right)(\mathrm{MPa} \cdot \sqrt{ } \mathrm{m})$ & $1.5-3$ & $5-8$ \\
\hline Fracture energy $\left(\mathrm{J} \cdot \mathrm{m}^{-2}\right)$ & $4-10$ & $\sim 60$ \\
\hline Modulus of elasticity $\left(25^{\circ} \mathrm{C}\right)(\mathrm{GPa})$ & $120-220$ & $300-330$ \\
\hline Thermal conductivity $\left(25^{\circ} \mathrm{C}\right)(\mathrm{W} / \mathrm{m} \cdot \mathrm{K})$ & $4-30$ & $15-50$ \\
\hline Thermal shock resistance $\mathrm{R}(\mathrm{K})$ & $220-580-780$ \\
\hline Thermal shock fracture toughness $\mathrm{R}{ }^{\prime}\left(\mathrm{W} \cdot \mathrm{m}^{-1}\right)$ & $500-10,000$ & $7000-32,000$ \\
\hline Coefficient of thermal expansion $\left(10^{-6} \mathrm{~K}^{-1}\right)$ & 2.5 & 3.2 \\
\hline Specific heat capacity $(\mathrm{J} / \mathrm{kg} \cdot \mathrm{K})$ & 720 & 800 \\
\hline Poisson ratio & 0.24 & 0.27 \\
\hline
\end{tabular}

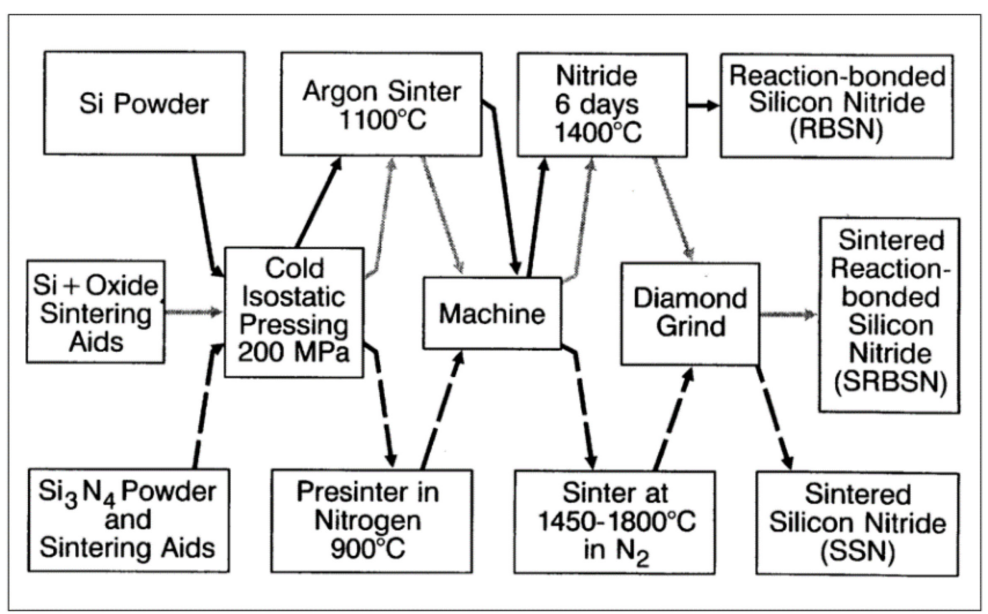

Figure 2. Processing routes to manufacture monolithic silicon nitride compacts [6,7]. (C) With permission from Wiley-VCH.

Porous reaction-bonded silicon nitride (RBSN), dense sintered reaction bonded silicon nitride (SRBN) and dense sintered silicon nitride (SSN) are the main sintering methods used for $\mathrm{Si}_{3} \mathrm{~N}_{4}$ as a biomaterial and hence, are described in more detail below.

The processing of RBSN starts from fine compacted silicon powders that during prolonged heating in nitrogen or ammonia atmospheres between 1000 and $1450{ }^{\circ} \mathrm{C}$ result in a mixture of $\alpha$ - and $\beta-\mathrm{Si}_{3} \mathrm{~N}_{4}$ polymorphs. No shrinkage during nitriding occurs because 
the volume increase of about $22 \%$ will be fully accommodated by the void spaces between the silicon powder particles. Hence, the outside dimensions of the green ceramics will be connaturally retained. This is the reason why RBSN is predominantly used to manufacture complex shaped components without the need for expensive post-sintering machining with diamond tools, making RBSN parts economically highly competitive. Although the porosity of RBSN is between 20 and $30 \%$, its mechanical performance is remarkable as flexural strengths values up to $350 \mathrm{MPa}$ can readily be attained (Table 1) [6]. An example for the medical application of RBSN is the porous inner body of the intervertebral spacer shown below.

To fabricate fully dense SSN monolithic devices, hot (HP) or hot isostatic pressing (HIP) is performed starting from powders to which oxides of magnesium, aluminum or yttrium as binder materials are added. At temperatures beyond $1550^{\circ} \mathrm{C}$, these oxides form, together with a contaminant silica film surrounding individual silicon nitride particles, a thin molten quinary $\mathrm{Si}-\mathrm{Al}-\mathrm{Y}-\mathrm{O}-\mathrm{N}$ glass film able to readily dissolve silicon nitride, resulting in the efficient densification of the ceramic body. However, there is a catch. Both $\mathrm{HP}$ and HIP sintering techniques are rather expensive and also limited to simple geometric shapes that, however, are rarely sufficient for biomedical devices and applications. Critical parameters of SSN processing are (i) powder particle sizes in the 100 to $200 \mathrm{~nm}$ range; (ii) the capability of binder oxides to form a liquid phase around silicon nitride grains; (iii) a high-pressure nitrogen atmosphere to prevent thermal dissociation; and (iv) sinter temperatures up to $1850{ }^{\circ} \mathrm{C}$. During processing in the presence of aluminum oxide and yttrium oxide reactants, $\mathrm{Al}$ and $\mathrm{O}$ ions are able to enter the $\mathrm{Si}_{3} \mathrm{~N}_{4}$ structure to form various SiAlON alloy components. The cooling of the intergranular liquid grain boundary film results in glassy and/or crystalline (YAG) phases, depending on the cooling rate [6]. An example for the medical application of SSN is the dense outer body of the intervertebral spacer, as shown below.

To manufacture strong and mechanically resilient silicon nitride monolithic shapes [9], an advanced texturing technique has been applied [10]. During the high temperature densification of powder compacts, the low temperature $\alpha-\mathrm{Si}_{3} \mathrm{~N}_{4}$ phase transforms to $\beta-\mathrm{Si}_{3} \mathrm{~N}_{4}$, and by so-called texturing a rod-like morphology is generated with a specific microstructure that drastically reinforces the mechanical and thermal performance of the final monolithic end product. To speed up the conversion rate, seeds of $\beta-\mathrm{Si}_{3} \mathrm{~N}_{4}$ are being added to the $\alpha-\mathrm{Si}_{3} \mathrm{~N}_{4}$ precursor powder. The rod-like $\beta-\mathrm{Si}_{3} \mathrm{~N}_{4}$ crystallites will be forced to align by hot pressing, hot forging or sinter forging, or by template grain growth (TGG) followed by cold pressing, slurry extrusion, tape casting, or static or rotating magnetic fields $[6,8]$.

\subsection{Synthesis and Properties of Silicon Nitride Thin Films and Coatings}

In many industrial applications, it is required to strengthen, protect and/or functionalize the surface of low-grade materials by adding a suitable high-grade coating. The decisive advantage of modern coating technology is that it marries two dissimilar materials to improve, in a synergistic way, the mechanical, chemical, tribological, corrosive, optical or biological performance of the 'tandem' structure substrate/coating. Frequently, the mechanical strength and fracture toughness are provided by a low-cost bulk metallic substrate, while a high-cost thin coating applied to its surface provides sufficient protection against environmental degradation by corrosion, wear, erosion, and by thermal and biological attack.

The viability of the biomedical application of silicon nitride coatings is currently under investigation as bearing surfaces for arthroplastic implants based on their low wear rate as well as their excellent biocompatibility [11]. However, attempts to deposit mechanically stable, thick and well-adhering silicon nitride coatings for biomedical application by thermal spraying was not met with resounding success; such coatings only contained rather small amounts of silicon nitride and substantial amounts of embrittling metal silicides, binder ceramic materials, and unreacted precursor materials $[6,7,12]$. 
Since the deposition of silicon nitride coatings on metallic substrates requires the addition of binder metal oxides such as $\mathrm{Al}_{2} \mathrm{O}_{3}+\mathrm{Y}_{2} \mathrm{O}_{3}$, no phase-pure homogeneous silicon nitride coatings could be produced to date. This problem was, at least partially, solved by spraying particles with high velocities up to $3 \mathrm{~km} / \mathrm{s}$ that were generated by an electromagnetically accelerated plasma (EMAP). Under these extreme conditions, dense, homogeneous silicon nitride coatings with reduced amounts of binder oxides could be deposited with suitable mechanical properties, including tight adhesion to the surface of polished stainless steel $[13,14]$.

Figure 3 shows that such dense and well-adhering, mechanically stable silicon nitridebased coatings on austenitic stainless-steel substrates deposited by conventionally detonation spraying (left) and ultrahigh-velocity pulsed plasma spraying, EMAPS (right). However, at the time of the writing, the novel technology has not progressed to a state where the pulsed mode could be replaced by a continuous delivery mode. Consequently, the deposition process is still economically untenable while tedious, since after each 'shot', the detonation chamber must be refilled with powder to be ready for the next shot. Nevertheless, this advanced deposition method may be at the cutting edge of future medical coating technologies designed for silicon nitride coatings as a protective bearing surface for novel arthroplastic devices or ceramic hip resurfacing (HR) prostheses (see below).
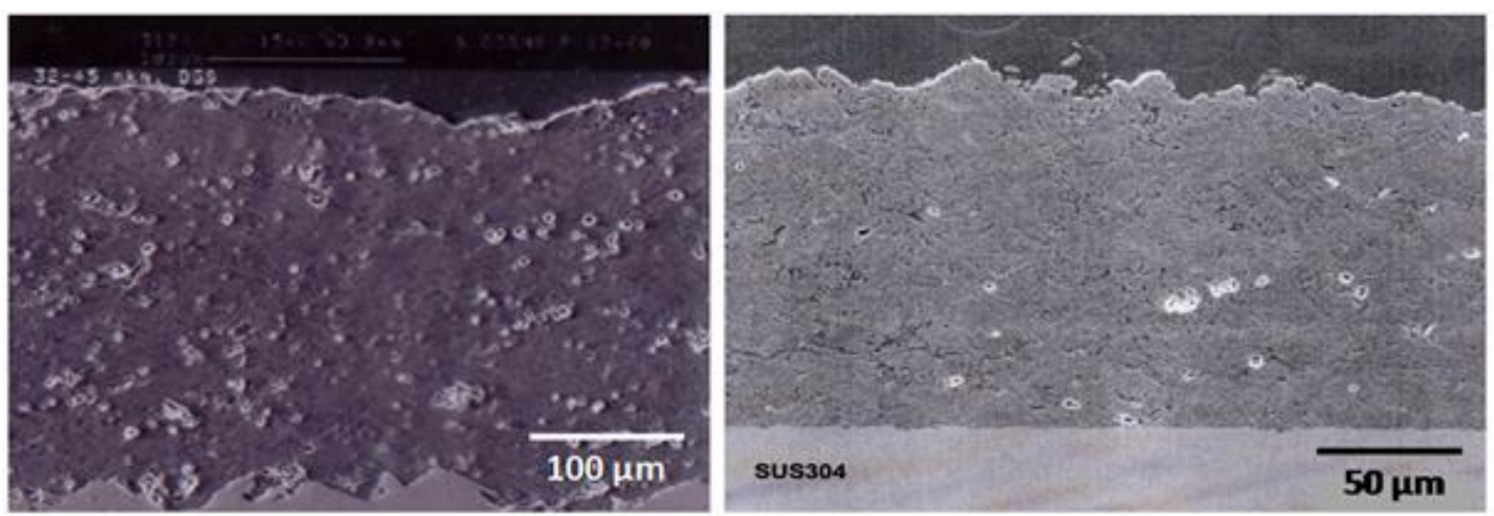

Figure 3. Silicon nitride-based coatings on austenitic stainless steel produced by detonation spraying (left) and ultrahigh velocity pulsed plasma spraying (right) [12]. (c) With permission from Wiley-VCH.

In a similar development, a magneto-plasma-dynamic (MPD) arc jet generator was utilized to deposit silicon nitride coatings by reactively spraying material from a crystalline silicon rod in a nitrogen atmosphere [15]. After 200 shots at a frequency of $0.03 \mathrm{~Hz}$ with a discharge current of $9 \mathrm{kA}, 30 \mu \mathrm{m}$ thick, dense and homogeneous $\mathrm{B}_{-}-\mathrm{Si}_{3} \mathrm{~N}_{4}$ coatings could be deposited.

Recently, additive manufacturing techniques such as robocasting have been enlisted for producing silicon nitride scaffolds with controlled porosity and suitable mechanical properties. Details can be found in Section 4.3 below.

\section{Biomedical Applications}

Although non-oxide ceramics such as silicon nitride are predominantly being used in high-temperature applications, including in parts of advanced gas turbines [16], turbocharger rotors for high-performance automotive engines [17] and rocket thrusters [18], more recent research results have strongly encouraged the use of silicon nitride in a variety of biomedical applications $[19,20]$. Silicon nitride excels by a unique combination of bulk mechanical and surface chemical properties, thus making it a close to ideal biomaterial for orthopedic implants. It is already being used copiously for interbody spinal fusion cages and is being developed for total joint arthroplasty. Its surface texture and chemistry are both highly tunable, yielding physicochemical combinations of properties that may lead to enhanced osseointegration and bacterial and viral resistance [4]. 
On top of the superior mechanical, thermal and chemical properties, silicon nitride ceramics have demonstrated high cell adhesion and enhanced osteoconductivity similar to non-stoichiometric (Ca-deficient) biological hydroxylapatite [21,22]. This advantageous feature is thought to be based on the zwitterionic-like behavior of silicon nitride that is a function of the tradeoff between positively charged vacancies in the partial $\mathrm{N}$ lattice of suitable doped silicon nitride and negatively charged silanol groups at its surface [19].

\subsection{Intervertebral Spacers}

Spinal implants are used to alleviate many forms of back pain and deformity including trauma-based injuries and disorders such as scoliosis, kyphosis, degenerative disc disease, and fracture. Their primary function is to help to fuse two vertebrae together and to replace natural disc material. The four types of surgery that utilize spinal implants are anterior, posterior, transforaminal lumbar interbody, and axial fusions.

Silicon nitride has been in clinical use for porous intervertebral spacers in spinal fusion surgery for over thirty years, without showing any undesirable long-term effects [23-27]. Silicon nitride possesses high strength, long-term resilience, mechanically reliable, and osseoconductive properties, partly based on a high proportion of covalent bonds. To achieve interbody fusion, the ability of silicon nitride to yield superior new bone ingrowth and osseointegration, along with its proven bacteriostatic properties and enhanced medical imaging, outperforms both conventional poly(ether ether ketone, PEEK) and titanium implants $[28,29]$. This is largely based on its pronounced hydrophilicity that attracts extracellular fluid rich in bone growth-mediating non-collagenous proteins, turning on osteoblasts and suppressing osteoclasts. Consequently, silicon nitride speeds up bone healing, bone fusion and thus, implant integration. The efficacy of silicon nitride for spinal reconstruction is supported by its strong bacterial resistance caused by the synergetic effects of surface chemistry, surface $\mathrm{pH}$, texture, and electric charge [26].

Anterior cervical discectomy with fusion is a commonly applied surgical procedure to treat radicular arm pain. A study compared silicon nitride implants with PEEK cages filled with autograft harvested from osteophytes [30]. Patients treated with either silicon nitride or PEEK implants reported comparable recovery rates during follow-up interviews. No significant differences in clinical outcome were noticed at 24 months observation time. Fusion rates improved over time and were comparable between both groups. Figure 4 shows the Valeo CCsC ${ }^{\circledR}$ (SINTX Technologies, Salt Lake City, UT) silicon nitride cervical interbody fusion device used in the CASCADE trial with radiographic characteristics. The outer part of the device consists of dense silicon nitride, whereas the inset comprises cancellous structured ceramic (CSC) of the same composition, providing a scaffold for easy bone ingrowth [31].

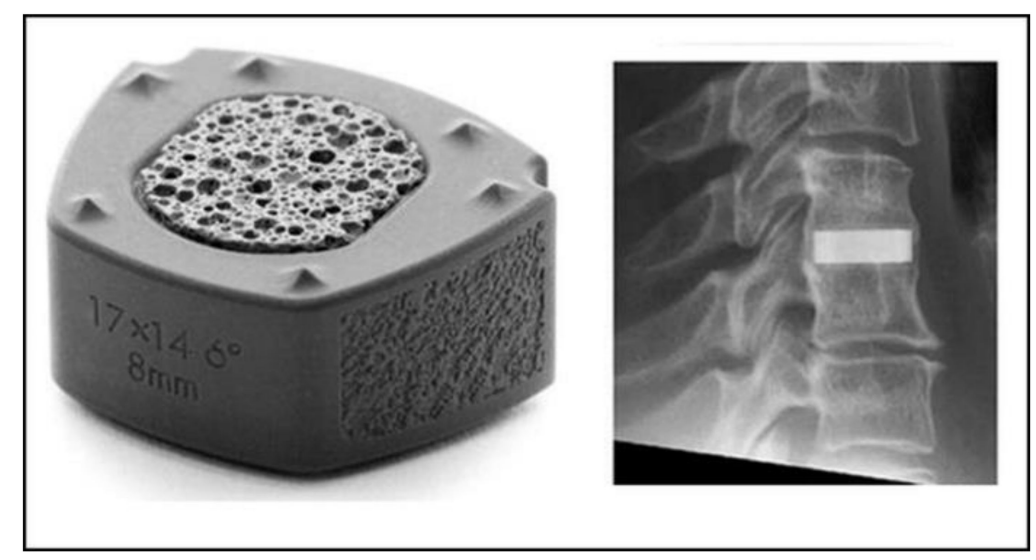

Figure 4. Silicon nitride cervical interbody fusion device (Valeo CCsC ${ }^{\circledR}$, left) with the radiographic image of the implanted device (right) [30]. (C) Creative Commons Attribution 4.0 International License. 


\subsection{Knee- and Hip Endoprosthetic Implants}

Silicon nitride compacts can be polished to a high surface finish to provide an exceptionally smooth, wear-resistant, and tribological superior surface. This renders the material ideal for articulating applications including bearings for knee and hip endoprostheses [32-34] as well as acetabular cups. Salient materials properties conducive to supporting bearing applications are phase stability [35], wear resistance [35,36], strength and fracture toughness [37], hydrophilicity [38], favorable medical imaging capability [26], and unsurpassed bacterial resistance $[28,39]$. Figure 5 shows a selection of silicon nitride compacts produced by SINTX Technologies of Salt Lake City, UT, USA, the only vertically integrated silicon nitride medical device manufacturer worldwide [22].

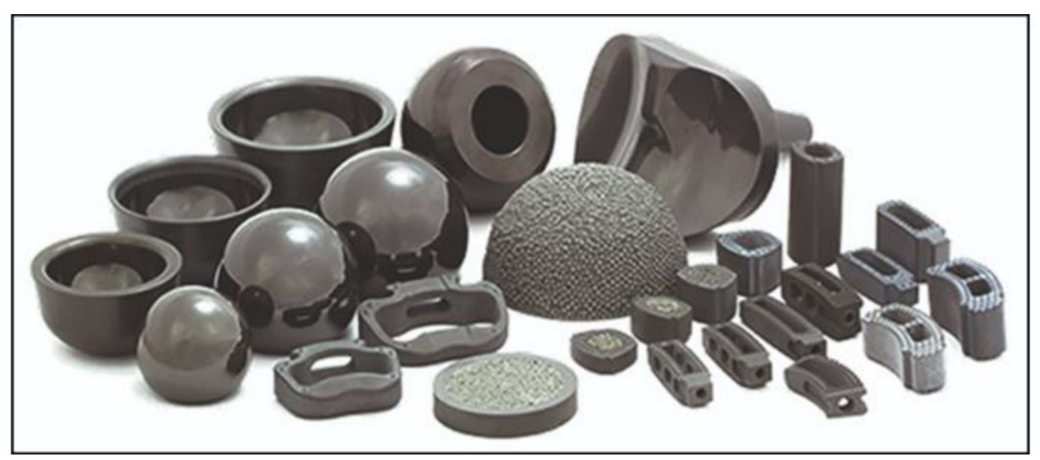

Figure 5. Various silicon nitride compacts produced by SINTX Technologies, Salt Lake City, UT, including ball bearings (left), an acetabular cup (center), an intervertebral spacer with a CSC core (foreground, center), and spinal interbody fusion devices (right) [22]. (C) Creative Commons Attribution 4.0 International License.

Silicon nitride ceramics were found to be highly biocompatible and non-cytotoxic as revealed by culture tests with mouse fibroblasts (L-929 cell line) and human mesenchymal stem cells (hMSCs) [40]. The excellent cytocompatibility was confirmed by the outcome of live/dead cell staining and the pronounced differentiation towards osteoblasts. Biocompatibility was also confirmed by the tissue response around the cylindrical silicon nitride implants installed in the tibiae of rabbits [41]. Histological analysis showed that bone growth occurred preferentially in the cortical area, and different types of tissue were identified on the implant surfaces such as lamellar bone tissue containing osteocytes and osteons, non-calcified matrix containing osteoblasts as well as collagen type III, that might in time be converted to collagen type I.

Tribological hip simulator tests showed a very low friction coefficient that decreased to still lower values when the articulating time was increased. This was likely caused by the hydrodynamic action of a self-lubricating hydrogen-terminated silicon oxide boundary film that develops during prolonged experimental articulation in an aqueous environment [42].

Silicon nitride with a high degree of covalent bonding was found to possess significantly higher mechanical strength compared to oxide ceramics such as $\mathrm{Al}_{2} \mathrm{O}_{3}$ or $\mathrm{ZrO}_{2}$ with predominantly ionic bonds. Finite element analysis (FEA) revealed a stress distribution within a femur, implanted with a silicon nitride prosthesis, comparable to that of an intact and healthy one. However, as a comparison was made between a $\mathrm{CoCr}$ prosthesis with a stem and a stemless $\mathrm{Si}_{3} \mathrm{~N}_{4}$ prosthesis, configurational differences, i.e., the presence or absence of a stem may override the material's advantage, i.e., $\mathrm{CoCr}$ alloy or $\mathrm{Si}_{3} \mathrm{~N}_{4}$ [43]. Moreover, lifetime prediction studies showed conclusively that implants made from silicon nitride are mechanically reliable and consequently, may be suitable for use in arthroplastic endoprostheses. These results strongly suggest that non-oxide ceramics such as silicon nitride with high mechanical strength may be useful future biomaterial candidates for highly loaded ceramic hip resurfacing (HR) endoprostheses based on their low wear rate, low friction coefficient, and pronounced biocompatibility and antibacterial properties [44]. 
However, there is a drawback. The high modulus of elasticity of HPSN and SSN in excess of $300 \mathrm{GPa}$ prohibits the use of these ceramic materials for load-bearing stems of hip implants, based on the effect of strong stress shielding that is caused by the large gradient of the modulus of elasticity between implant material and cortical bone. Although RBSN with a noticeably lower elastic modulus around $150 \mathrm{GPa}$ has been suggested as a viable alternative option for this particular application, the modulus is still an order of magnitude higher than that of the cortical bone that shows values around $20 \mathrm{GPa}$ [6]. Moreover, as a consequence of the high porosity of RBSN, both flexural strength (150-350 MPa) and fracture toughness $(1.5-3 \mathrm{MPa} \cdot \sqrt{ } \mathrm{m}$ ) are substantially below those of HPSN and SSN (see Table 1) $[6,8]$.

In contrast, acetabular cups based on silicon nitride have already found their way into the orthopedic operation theater [45]. In the majority of hip endoprosthetic implants, the femoral head articulates against an acetabular cup liner composed of tough polymers such as ultra-high molecular weight polyethylene (UHMWPE) or X-linked polyethylene. These polymers degrade over time by chain scission and thus, strategies must be applied to delay this deterioration, including radiative cross-linking [46] or doping with antioxidants such as vitamin E [47]. Owing to the unique surface chemistry of silicon nitride, this material is able to absorb oxygen the released from degrading polyethylene [48], thus limiting acetabular liner degradation in hip endoprostheses. This also helps to avoid polymer wear debris that is known to cause the so-called 'particle disease' that may lead to the aseptic loosening of the implant within the femur by periprosthetic osteolysis [49], and when distributed by the lymphatic system throughout the body, may cause hepatic degeneration.

Frequently, CoCrMo alloys such as ASTM F75-12 or ASTM F1537 are utilized as hip endoprosthetic stem materials [1], with high implant survival rates. However, certain risks including accelerated wear rates and the release of cytotoxic $\mathrm{Co}$ and $\mathrm{Cr}$ ions limit their usefulness. In a recent study [11], $4 \mu \mathrm{m}$-thick silicon nitride $\left(\mathrm{SiN}_{\mathrm{x}}\right)(\mathrm{N} / \mathrm{Si}=1.10$ to 1.25$)$ coatings were deposited by reactive d.c. magnetron sputtering onto CoCrMo surfaces, with a 0.5 to $0.8 \mu \mathrm{m} \mathrm{CrN}$ bond coat applied to increase adhesion. Wear tests performed against $\mathrm{Si}_{3} \mathrm{~N}_{4}$ in a ball-on-disc tribometer revealed specific wear rates essentially below those of CoCrMo. Similar results were obtained by Maria Petterson as reported in her Ph.D. thesis [50]. To address the question of cytotoxicity, the role of particle size, surface composition and donor variations of silicon nitride on its biological impact were investigated [51]. Cytotoxicity, inflammatory cytokine release, oxidative stress, and the genotoxic potential of silicon nitride and $\mathrm{CoCr}$ particles were tested and compared using human peripheral blood mononuclear cells (hPBMNCs). The minimum biological impact of silicon nitride on human PBMNCs was recorded as opposed to $\mathrm{CoCr}$ particles that showed significantly higher levels of TNF- $\alpha$ cytokine release, oxidative stress, and DNA damage, confirming that silicon nitride, when properly engineered, is an attractive orthopedic biomaterial for joint replacement devices.

Silicon nitride ceramics with titania, calcia and silica additives enabled the production of silicon nitride ceramics with improved mechanical properties, and the absence of cytotoxicity and microstructures containing elongated grains of $\beta-\mathrm{Si}_{3} \mathrm{~N}_{4}$. $\mathrm{TiO}_{2}$ was found to promote densification, fracture toughness, reactivity in SBF and in vitro cell proliferation. The presence of $\mathrm{TiO}_{2}$ causes the crystallization of a TiN grain boundary phase that may ease the production of materials for orthopedic devices by using advanced manufacturing methods such as electrical discharge machining [52].

\subsection{Bone Grafts and Scaffolds}

Bone grafting is a surgical procedure that uses transplanted bone to repair and rebuild diseased or damaged bones. In the clinical practice, bone grafts present limitations that include harvesting morbidity, insufficient bioactivity, and concern about the transmission of diseases [25]. Silicon nitride bone scaffolds and bone fusion devices [53] excel by high and reliable mechanical strength, biocompatibility, and antibiotic capability, resulting in a bone healing sequence comparable to hydroxylapatite [19]. However, there is a caveat. 
Using silicon nitride for permanent scaffolds is counter-indicated by its apparent lack of in vivo resorbability, a necessary and sufficient requirement for the replacement of implant material by natural bone. In contrast, non-stoichiometric $\mathrm{SiN}_{\mathrm{x}}$ coatings very slowly dissolve in simulated body fluid at a rate of about $0.3 \mathrm{~nm} /$ day [50].

MC3T3-E1 cells were used to study the osteoblastic differentiation and mineralization on sterile samples of silicon nitride, and compared them to samples of titanium and PEEK, standard materials for bone scaffolds [54]. The study reported a more profound and faster ECM deposition and mineralization on $\mathrm{Si}_{3} \mathrm{~N}_{4}$ surface as compared to titanium and PEEK. Results further indicated the upregulation of osteogenic transcription factors such as RUNX2 and osterix (SP7), as well as collagen type I and osteocalcin. Hence, silicon nitride rapidly conducts mineralized tissue formation via extracellular matrix deposition and biomarker expression in murine calvarial pre-osteoblast cells.

In the quest to obtain highly porous $\mathrm{Si}_{3} \mathrm{~N}_{4}$ scaffolds for bone reconstruction with a substantially reduced modulus, recently additive manufacturing (AM) techniques have been proposed such as stereolithography, selective laser sintering (SLS) or robocasting. Robocasting [55] uses robotics to control the deposition of silicon nitride slurries ('inks') with suitable viscosity by extrusion through an orifice and the subsequent spark plasma sintering, allowing the near-net shape formation of ceramic structures [56]. This offers advantages including the precise control of channel size and shape as well as versatility in designing geometrically complex structures [57]. This technique provides means to adjusting the porosity and mechanical properties to match those of bone tissue. The adsorption capability of proteins on robocast $3 \mathrm{D}-\mathrm{Si}_{3} \mathrm{~N}_{4}$ scaffolds was confirmed, thus suggesting osseoconductive potential [58]. Among the many advantages of this novel technique, the possibility to manufacture silicon nitride devices with a drastically reduced modulus of elasticity stands out.

\subsection{Dental Implants}

Silicon nitride is an emerging material for dental restoration and dental implant application. In addition to its excellent structural, mechanical, thermal, tribological and biocompatible properties, silicon nitride is a potent antibacterial material. Dental implants made from silicon nitride are thought to exhibit favorable mechanical properties compared to classic titanium alloy implants [59]. Hence, in view of scant available pre-clinical data, silicon nitride appears to have the essential characteristics to be a strong candidate for dental implants' material. This novel ceramic has a surface with potentially antimicrobial properties, and if this is confirmed in future research, it could be of great interest for oral use $[60,61]$. However, at this point in time, there are no clinical studies and trials are yet to confirm the positive changes silicon nitride may elicit as a dental implant material. Further research and clinical trials into the in vivo performance of antibacterial surface coatings such as enhancing bone regeneration around the implant surface or reducing the risk of periimplantitis [59].

An earlier study [62] investigated the potential use of porous silicon nitride for allceramic dental restorations as a core material and results were compared with those of a commercial $\mathrm{ZrO}_{2}$ ceramic. The color of silicon nitride could be tailored by the porosity introduced and a color shade suitable for restorative applications was obtained. The flexural strength of $\mathrm{Si}_{3} \mathrm{~N}_{4}$ was found to be $418 \mathrm{MPa}$ despite an open porosity of nearly $10.5 \%$ (cp. Table 1). This rather high strength may be related to the strong neck formation between $\beta$ $\mathrm{Si}_{3} \mathrm{~N}_{4}$ grains, the intertwined distribution of these grains, and the crack deflection potential of rod-like $\beta-\mathrm{Si}_{3} \mathrm{~N}_{4}$. The Vickers hardness of $\mathrm{Si}_{3} \mathrm{~N}_{4}$ was found to be $10.9 \mathrm{MPa}$ whereas $\mathrm{ZrO}_{2}$ had $13.7 \mathrm{MPa}$, which reduces the risk of the wear of opposing natural teeth. Shear bond strength to dentin was tested and indicated low values for silicon nitride without a coupling agent $(2.24 \pm 1.15 \mathrm{MPa})$, which strongly increased by adding a silane coupling agent to $8.44 \pm 2.98 \mathrm{MPa}$, suggesting that the usage of coupling agents for $\mathrm{Si}_{3} \mathrm{~N}_{4}$ is essential. The radiolucent behavior of $\mathrm{Si}_{3} \mathrm{~N}_{4}$ will enable for both the restorations and the surrounding tissues to be imaged using plain radiography (Figure 6). Hence, this study shows that with 
the tailored manufacturing methods including additive manufacturing, silicon nitride can be considered an effective dental restorative material.

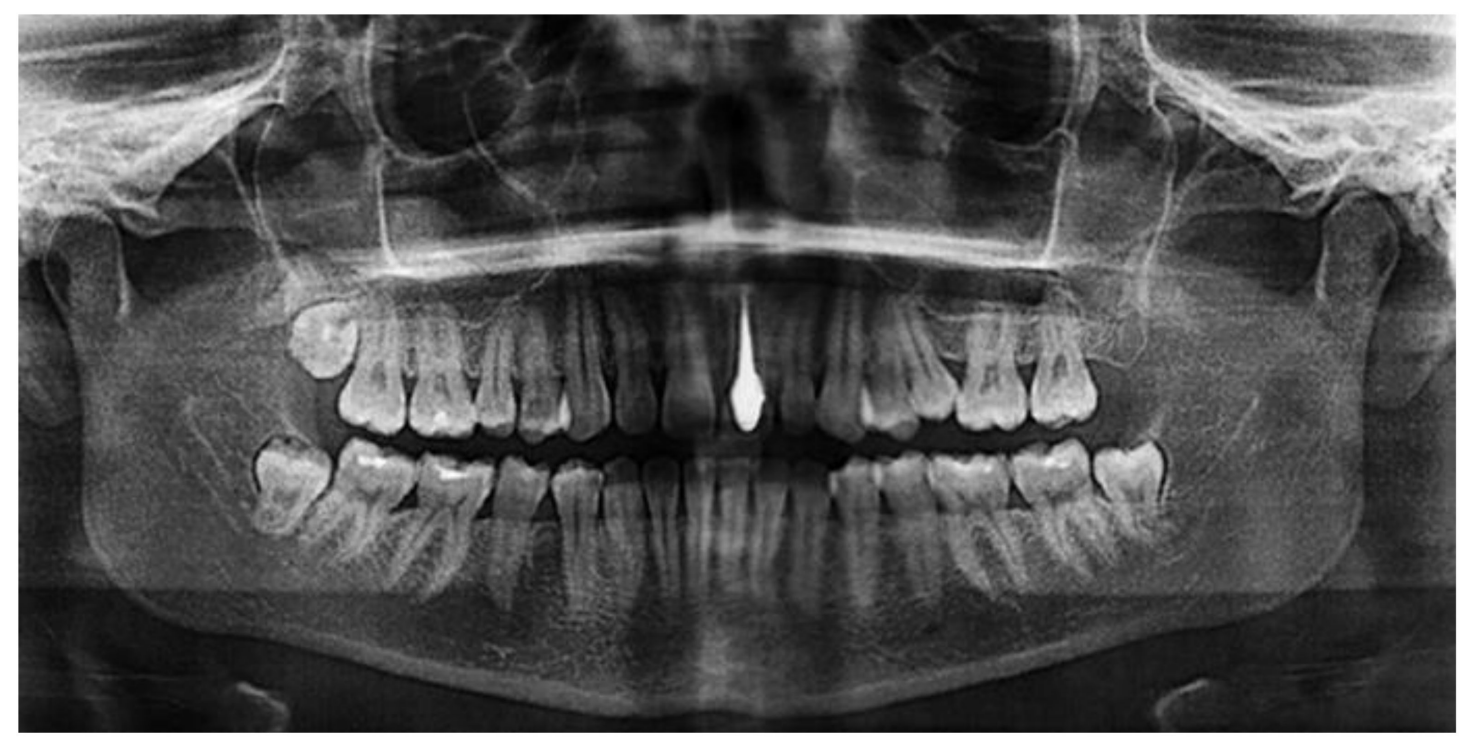

Figure 6. Silicon nitride as a material for dental core restoration, revealing radiolucency [63]. (C) Creative Commons Attribution 4.0 International License.

White silicon nitride can be prepared by pressureless sintering at $1650{ }^{\circ} \mathrm{C}$ in a nitrogen atmosphere [61]. In a recent study [64], partially sintered $\mathrm{Si}_{3} \mathrm{~N}_{4}$ ceramic blocks were prepared by heating to $1400{ }^{\circ} \mathrm{C}$ in a $\mathrm{N}_{2}$ gas environment. After full sintering at $1650{ }^{\circ} \mathrm{C}$ for $2 \mathrm{~h}$, the linear shrinkage value was recorded at $19.9 \pm 0.6 \%$. The flexural strength and fracture toughness were measured, for which the results were $891.2 \pm 37.2 \mathrm{MPa}$ and $6.3 \pm 0.30 \mathrm{MPa} \cdot \sqrt{ } \mathrm{m}$, respectively. In conclusion, white $\mathrm{Si}_{3} \mathrm{~N}_{4}$ can be favorably used to fabricate multi-unit dental restorations conforming to ISO 6872 designation [65].

Although zirconia is still the most commonly used ceramic for dental implants, its intrinsic bioinert nature often results in a lack of biological integration. A silicon nitridebased laser-cladding process has been developed to improve the biological response to biomedical zirconia by forming a composite coating with $\mathrm{Si}_{3} \mathrm{~N}_{4}$ particles dispersed in a nano-crystalline/amorphous silicon matrix. Raman spectroscopy revealed that the bone tissue quality parameters were comparable to healthy human bone tissue, suggesting that laser-cladding with silicon nitride might be able to improve the stability of zirconia dental implants [66].

In conclusion, the metal-free nature of silicon nitride makes this material a promising candidate for dental implantology as a release of cytotoxic metallic by-products able to invade any part of the body can be avoided. Higher esthetics, better osseointegration and biocompatibility, antibacterial property along with a high wear resistance and metal-free corrosion products render silicon nitride a powerful contender for dental implant application.

\subsection{Intelligent Synthetic Neural Circuits}

Synthetic regulatory circuits encoded in RNA rather than DNA could provide a means to control cell behavior while avoiding potentially harmful genomic integration in therapeutic applications. Post-transcriptional circuits have been developed using RNA-binding proteins that can be wired in a plug-and-play fashion to create networks of higher complexity [67]. Application of this research in the realm of future information technology include signal transmission platforms for artificial intelligence (AI) algorithms with unparalleled computing speed based on novel synthetic neural circuits.

A neuron cell culturing platform consisting of arrays of ordered silicon nitride microtubes (2.7-4.4 $\mu \mathrm{m}$ in diameter) was formed by strain-induced self-rolled-up nano- 
membrane (s-RUM) technology using ultrathin $(<40 \mathrm{~nm}$ ) silicon nitride films deposited on transparent substrates such as glass [68]. These microtubes presented strong guidance for fast growing primary cortical neurons, with a coaxially confined configuration resembling that of myelin sheaths. Neurons revealed a dramatically enhanced growth rate inside the microtube compared to regions outside the microtubes. The acceleration and precise guidance provided by the silicon nitride microtube array was attributed to 3D-adhesion and electrostatic interaction with the silicon nitride microtubes, respectively. The microtubes not only provide structure for the neural network and guiding connections, but also accelerate the growth of axons, an important feature as time is crucial for restoring severed connections in the case of spinal cord injury or limb reattachment. A time-lapse sequence of a cortical neuron rapidly growing from inside a microtube through neighboring microtubes can be watched on the Internet [69].

This research has important implications for designing and building intelligent synthetic neural circuits for the potential treatment of neurological disorders. In addition, the novel self-rolled-up silicon nitride microtubes could provide an ideal route to integrate electrodes into neural cultures, coupled with photonics, to directly monitor dynamic neural activities and record action potentials with enhanced resolution and fidelity [70].

In conclusion, self-rolled-up silicon nitride microtubes are attractive for photonic, electronic, and biological applications based on their transparency under visible light, tunable refractive index, non-toxicity, and compatibility with Si-integrated circuits [71]. Thus, they may become important additions to the toolbox of fourth generation biomaterials that will be integrated with the human body to provide powerful diagnostic and therapeutic capability able to manipulate, amplify and monitor bioelectric cellular signals that are important for tissue regeneration and eventually allowing for communication with the host tissues [1,72].

\subsection{Antibacterial and Antiviral Particles and Coatings}

The efficacy of silicon nitride as a 'killer ceramics' for Gram-negative bacteria such as Porphyromonas gingivalis was found to be the result of chemically-driven mechanisms related to the peculiar $\mathrm{pH}$-dependent surface chemistry of silicon nitride [39]. In an alkaline $\mathrm{pH}$ environment, a buffering effect controlled by the release of ammonium $\left(\mathrm{NH}_{4}{ }^{+}\right)$ions causes the lysis of bacterial proteins as confirmed by conventional fluorescence and in situ Raman microprobe spectroscopies. The formation of peroxinitrite within the bacteria leads to the degradation of nucleic acid, and reductions in phenylalanine content and liquid concentration were observed. Experiments confirmed that the modification of the surface chemistry of silicon nitride by chemical etching or thermal oxidation influenced the peroxinitrite formation and thus, affected bacteria metabolism.

Polyethylene coated by pulsed laser technique with silicon nitride powder in a nitrogen gas atmosphere showed antibacterial properties in vitro against $\mathrm{S}$. epidermidis. The coating sensibly reduced the amount of living bacteria when compared to the uncoated polymer. Osteoconductivity was also tested in vitro using SaOS-2 osteosarcoma cells. The presence of the silicon nitride coating resulted in an increased amount of hydroxyapatite deposited from extracellular fluid (ECF). Hence, the coating of polyethylene with silicon nitride may lead to the improved performance of orthopedic endoprosthetic medical devices [73].

Polyether ether ketone (PEEK) used for intervertebral spacers has shortcomings including a lack of osseoconductivity and radiolucency as well as poor antibacterial resistance. Adding up to $15 \mathrm{vol} \%$ of $\mathrm{Si}_{3} \mathrm{~N}_{4}$ powder to PEEK results in significant improvement of radiolucency, osseoconductivity versus SaOS-2 cells, and bacteriostatic property versus Gram-positive S. epidermidis bacteria [74].

To confront the challenge of bacterial resistance to antibiotic treatment has become one of the most critical issues of present medical research. Methicillin-resistant strains of S. aureus (MRSA) are major killers of patients in hospitals or other health care settings, such as nursing homes and dialysis centers. In these settings, the harmful bacteria are known as 
healthcare-associated MRSA (ha-MRSA). A study has found that the antimicrobial behavior of machined $\mathrm{Si}_{3} \mathrm{~N}_{4}$ surfaces was due to the repulsion of the bacteria, a phenomenon that also limited osteogenesis, as host cells were also unable to adhere to the machined surface. This suggests that the in vivo biological behavior of $\mathrm{Si}_{3} \mathrm{~N}_{4}$ orthopedic implants is driven by critical features of their surface nanotopography [75].

Silicon nitride has been shown to inactivate several bacterial species and viral strains including SARS-CoV-2, while mammalian cells would remain unaffected [76]. SARS-CoV-2 virions $\left(2 \times 10^{4} \mathrm{PFU} / \mathrm{mL}\right.$ diluted in growth media) were exposed to $5,10,15$, and $20 \%$ $(w / v)$ of an aqueous suspension of sintered $\mathrm{Si}_{3} \mathrm{~N}_{4}$ particles for durations of 1,5 , and $10 \mathrm{~min}$, respectively. Following each exposure to $\mathrm{Si}_{3} \mathrm{~N}_{4}$, the remaining infectious virus was quantitated by plaque assay. It was found that the reduction in SARS-CoV-2 titers were markedly reduced when exposed to all concentrations of $\mathrm{Si}_{3} \mathrm{~N}_{4}$, showing reductions between 85 and $99.6 \%$, depending on the dose and duration of exposure. In conclusion, surface treatment strategies based on silicon nitride particles or coatings may offer novel methods to discourage SARS-CoV-2 persistence and infectivity on surfaces and thus, control the spread of the COVID-19 pandemic. Additional research has provided insight into the mechanism of the antiviral properties of silicon nitride [4]. Conceivably, it derives from a hydrolytic reaction of the silicon nitride surface [39] and the related formation of reactive nitrogen species (RNS) that could be easily metabolized by mammalian cells but that are lethal to pathogenic bacteria and ssRNA viruses. It was confirmed by PCR (polymerase chain reaction) tests that RNS directly react with viral proteins and RNA. Consequently, silicon nitride may play an important role in controlling the spread of human epi- and pandemics caused by ssRNA mutant viruses and other pathogens.

\subsection{Medical Diagnostics}

Cellular sampling and characterization include the culture, differentiation and fixing of cells on silicon nitride substrates for imaging and mapping across the electromagnetic spectrum, from X-ray fluorescence (XRF) to X-ray absorption near edge spectroscopy (XANES) to visible and infrared microspectroscopies [77]. Cells were found to adhere strongly to silicon nitride surfaces, allowing for investigation of visually displayed proliferative and phenotypic growth.

Lasers for medical application operate in a wide range of the electromagnetic spectrum, from X-ray up to UV, continue in the visible and near-infrared to mid-IR. These electromagnetic waves need to be transmitted from the laser source to the target tissue by a flexible device, called a waveguide, which will enable the easy manipulation of the laser beam in a medical diagnostic setting [78]. Novel integrated nano-photonic sensing devices operating in the visible and near-infrared regions with drastically reduced propagation losses were developed based on silicon nitride waveguides [79]. Silicon nitride is frequently chosen as the passive waveguide material due to its several advantages compared to silicon, including higher transparency at wavelengths below $1.1 \mu \mathrm{m}$, ultra-low two-photon absorption effect at telecommunication wavelengths, and ultimately, smaller propagation losses. These properties have made silicon nitride a widely used platform in silicon-integrated photonic applications [80].

In addition, silicon nitride waveguide-based nano-photonic integration platforms have potential for the miniaturization of optical coherence tomography systems [81,82]. Novel silicon nitride-based nano-photonic waveguides increasingly find applications in Raman spectroscopy to enhance signal strength [83] and to miniaturize chips for SERS (surface-enhanced Raman spectroscopy) [84].

The chemical activation of silicon nitride surfaces with either aqueous or organic solutions of 3-aminopropyl triethoxysilane led to the development of an optical biosensor allowing for the immobilization of biomolecules such as proteins by covalent bonding [85]. Protein immobilization was followed by incubation with murine $\gamma$-globulin and reaction with fluorescently labeled goat antimouse IgG antibody. Recording the surface fluorescence revealed improved signal intensity and reproducibility compared to other protocols. 


\section{Conclusions}

The research and development effort on silicon nitride has impressively shown that this unique ceramic biomaterial provides a host of advantageous properties conducive to application in modern medicine as part of prosthetic devices in orthopedic, dental, cardiovascular, ophthalmological, and reconstructive surgeries. These applications are based on highly compressive and flexural strengths, high fracture toughness, low friction coefficient, high wear and corrosion resistance, improved medical imaging ability as a radiolucent material, and enhanced biocompatibility, osseointegration and antimicrobial activity against bacteria and viruses. These unique properties suggest that silicon nitride is destined to become a leader to replace titanium and other entrenched biomaterials in many contemporary and future medical applications. However, as advantageous as the mechanical, tribological, chemical and biological properties of silicon nitride are, the comparatively high modulus of elasticity poses a challenge for the application of loadbearing stems for arthroplastic implants. Even though modulus reduction can be achieved by using porous RBSN instead of dense pressureless SSN, the modulus gradient between the implant and cortical bone is still too large to suppress effectively stress the shielding of hip endoprosthetic implants, in contrast to intervertebral spacers that have enjoyed lasting success for more than thirty years. To address this issue, modern ceramic processing techniques such as additive manufacturing may be enlisted to produce highly porous devices with a substantially reduced modulus of elasticity.

Funding: This research received no external funding.

Conflicts of Interest: The author declares no conflict of interest.

\section{References}

1. Heimann, R.B. (Ed.) Materials for Medical Application; Walter de Gruyter GmbH: Berlin, Germany, 2020.

2. Ivanova, E.P.; Bazaka, K.; Crawford, R.J. Bioinert ceramic biomaterials: Advanced applications. In New Functional Biomaterials for Medicine and Healthcare; Ivanova, E.P., Bazaka, K., Crawford, R.J., Eds.; Woodhead Publishing Series in Biomaterials; Woodhead Publ. Ltd.: Sawston, Cambridge, UK, 2014; pp. 187-219.

3. Heimann, R.B.; Lehmann, H.D. Bioceramic Coatings for Medical Implants; Wiley-VCH: Weinheim, Germany, 2015; pp. 253-308.

4. Pezzotti, G.; Boschetto, F.; Ohgitani, E.; Fujita, Y.; Zhu, W.; Marin, E.; McEntire, B.J.; Bal, B.S.; Mazda, O. Silicon nitride: A potent solid-state bioceramic inactivator of ssRNA viruses. Sci. Rep. 2021, 11, 2977. [CrossRef]

5. Spine Firm Jumps into Virus-Killing Mask Market. Available online: https://ryortho.com/breaking/spine-firm-jumps-intovirus-killing-mask-market (accessed on 13 March 2021).

6. Heimann, R.B. Classic and Advanced Ceramics. From Fundamentals to Applications; Wiley-VCH: Weinheim, Germany, 2010; pp. 457-467.

7. Cannon, W.R.; Gugel, E.; Leimer, G.; Woetting, G.; Heimann, R.B. Ceramics-Advanced Structural Products. In Ullmann's Encyclopedia of Industrial Chemistry, 7th ed.; Wiley-VCH: Weinheim, Germany, 2011; Chapter 4.4.

8. Heimann, R.B. Synthesis and properties of silicon nitride coatings. In Silicon Nitride: Synthesis, Properties and Applications; Hierra, E.J., Salazar, J.A., Eds.; Nova Science Publishers, Inc.: Hauppauge, NY, USA, 2012.

9. Riley, F.L. Application of silicon nitride ceramics. In Advanced Ceramic Materials; Mostaghaci, H., Ed.; Trans Tech Publications Ltd.: Baech, Switzerland, 1996; Volume 122, pp. 479-488. [CrossRef]

10. Zhu, X.; Sakka, Y. Textured silicon nitride: Processing and anisotropic properties. Sci. Technol. Adv. Mater. $2008,9,033001$. [CrossRef]

11. Filho, L.; Schmidt, S.; Leifer, K.; Engqvist, H.; Högberg, H.; Persson, C. Towards Functional Silicon Nitride Coatings for Joint Replacements. Coatings 2019, 9, 73. [CrossRef]

12. Heimann, R.B. Plasma Spray Coating. Principles and Applications, 2nd ed.; Wiley-VCH: Weinheim, Germany, 2008 ; pp. $267-270$.

13. Usuba, S.; Heimann, R.B. Dense Si3N4 Coatings with High Friction Coefficient Deposited by High-Velocity Pulsed Plasma Spraying. J. Therm. Spray Technol. 2006, 15, 356-363. [CrossRef]

14. Heimann, R.B. Thermal spraying of silicon nitride coatings using highly accelerated precursor powder particles. Surf. Coat. Technol. 2010, 205, 943-948. [CrossRef]

15. Tahara, H.; Yoshimura, N.; Koshiro, Y. Spraying using electromagnetically accelerated plasma. Solid State Phenom. 2007, 127, 319-321. [CrossRef]

16. McEntire, B.J.; Hengst, R.R.; Collins, W.T.; Taglialavore, A.P.; Yeckley, R.L. Advances in the development of silicon nitride and other ceramics. J. Eng. Gas. Turbines Power 1993, 115, 67-76.

17. Shimizu, T.; Takama, K.-I.; Enokishima, H.; Mikame, K.; Tsuji, S.; Kamiya, N. Silicon Nitride Turbocharger Rotor for High Performance Automotive Engines. SAE Tech. Paper Ser. 1990, 900656. [CrossRef] 
18. Eckel, A.J. Silicon Nitride Rocket Thrusters Test Fired Successfully. NASA Res. News. 2009. Available online: https://web.archive. org/web/20090404161958 (accessed on 22 March 2021).

19. Pezzotti, G.; McEntire, B.J.; Bock, R.; Boffelli, M.; Zhu, W.; Vitale, E.; Puppulin, L.; Adachi, T.; Yamamoto, T.; Kanamura, N.; et al. Silicon Nitride: A Synthetic Mineral for Vertebrate Biology. Sci. Rep. 2016, 6, 31717. [CrossRef]

20. Guedes e Silva, C.C. Silicon nitride as biomaterial. In Silicon Nitride: Synthesis, Properties and Applications; Hierra, E.J., Salazar, J.A., Eds.; Nova Science Publ. Inc.: New York, NY, USA, 2012; pp. 149-156.

21. Masuda, Y.; Inami, W.; Miyakawa, A.; Kawata, Y. Cell culture on hydrophilicity-controlled silicon nitride surfaces. World J. Microbiol. Biotechnol. 2015, 31, 1977-1982. [CrossRef] [PubMed]

22. The Story of Silicon Nitride. Orthopaedic Product News. Available online: www.opnews.com/2016/11/the-story-of-siliconnitride/13077 (accessed on 19 March 2021).

23. Sorrell, C.; Hardcastle, P.H.; Druitt, R.K.; Howlett, C.R.; McCartney, E.R. Results of 15-years clinical study of reaction-bonded silicon nitride intervertebral spacers. In Proceedings of the 7th World Biomaterial Congress, Sydney, Australia, 17-21 May 2004; Australian Society for Biomaterials: Sydney, Australia, 2004; p. 1872.

24. Guedes e Silva, C.C.; König, B., Jr.; Carbonari, M.J.; Yoshimoto, M.; Allegrini, S., Jr.; Bressiani, J.C. Bone growth around silicon nitride implants-An evaluation by scanning electron microscopy. Mater. Character. 2008, 59, 1339-1341. [CrossRef]

25. Anderson, M.C.; Olsen, R. Bone ingrowth into porous silicon nitride. J. Biomed. Mater. Res. Part A 2009, 92, 1598-1605. [CrossRef] [PubMed]

26. Anderson, M.; Bernero, J.; Brodke, D. Medical Imaging Characteristics of Silicon Nitride Ceramic: A New Material for Spinal Arthroplasty Implants. In Proceedings of the 8th Annual Spine Arthroplasty Society Glob. Symposium, Miami Beach, FL, USA, 6-9 May 2008; p. 547.

27. Taylor, R.M.; Bernero, J.P.; Patel, A.A.; Brodke, D.S.; Khandkar, A.C. Silicon nitride-A new material for spinal implants. J. Bone Jt. Surg. 2010, 92 (Suppl. 1), 133.

28. Bal, B.S.; Gorth, D.J.; Puckett, S.; Webster, T.J.; Rahaman, M.; Ercan, B. Decreased bacteria activity on Si3N4 surfaces compared with PEEK or titanium. Int. J. Nanomed. 2012, 7, 4829-4840. [CrossRef] [PubMed]

29. Webster, T.; Patel, A.; Rahaman, M.; Bal, B.S. Anti-infective and osteointegration properties of silicon nitride, poly(ether ether ketone), and titanium implants. Acta Biomater. 2012, 8, 4447-4454. [CrossRef] [PubMed]

30. Arts, M.P.; Wolfs, J.F.C.; Corbin, T.P. Porous silicon nitride spacers versus PEEK cages for anterior cervical discectomy and fusion: Clinical and radiological results of a single-blinded randomized controlled trial. Eur. Spine J. 2017, 26, 2372-2379. [CrossRef]

31. Arts, M.P.; Wolfs, J.F.; Corbin, T.P. The CASCADE trial: Effectiveness of ceramic versus PEEK cages for anterior cervical discectomy with interbody fusion; protocol of a blinded randomized controlled trial. BMC Musculoskelet. Disord. 2013, 14, 244. [CrossRef] [PubMed]

32. Zhou, Y.; Ohashi, M.; Tomita, N.; Ikeuchi, K.; Takashima, K. Study on the possibility of silicon nitride-Silicon nitride as a material for hip prostheses. Mater. Sci. Eng. C 1997, 5, 125-129. [CrossRef]

33. Mazzocchi, M.; Bellosi, A. On the possibility of silicon nitride as a ceramic for structural orthopaedic implants. Part I: Processing, microstructure, mechanical properties, cytotoxicity. J. Mater. Sci. Mater. Med. 2008, 19, 2881-2887. [CrossRef]

34. Mazzocchi, M.; Gardini, D.; Traverso, P.L.; Faga, M.G.; Bellosi, A. On the possibility of silicon nitride as a ceramic for structural orthopaedic implants. Part II: Chemical stability and wear resistance in body environment. J. Mater. Sci. Mater. Med. 2008, 19, 2889-2901. [CrossRef]

35. Bal, B.S.; Khandkar, A.; Lakshminarayanan, R.; Clarke, I.; Hoffman, A.A.; Rahaman, M.N. Testing of silicon nitride ceramic bearings for total hip arthroplasty. J. Biomed. Mater. Res. Part B Appl. Biomater. 2008, 87, 447-454. [CrossRef] [PubMed]

36. McEntire, B.J.; Bal, B.S.; Lakshminarayanan, R.; Bock, R. Silicon nitride bearings for total joint arthroplasty. Bone Joint J. 2016, 98 (Suppl. 1), 34. [CrossRef]

37. Bal, B.; Rahaman, M. Orthopedic applications of silicon nitride ceramics. Acta Biomater. 2012, 8, 2889-2898. [CrossRef]

38. Bock, R.M.; McEntire, B.J.; Bal, B.S.; Rahaman, M.N.; Boffelli, M.; Pezzotti, G. Surface modulation of silicon nitride ceramics for orthopaedic applications. Acta Biomater. 2015, 26, 318-330. [CrossRef] [PubMed]

39. Pezzotti, G.; Bock, R.M.; McEntire, B.J.; Jones, E.; Boffelli, M.; Zhu, W.; Baggio, G.; Boschetto, F.; Puppulin, L.; Adachi, T.; et al. Silicon Nitride Bioceramics Induce Chemically Driven Lysis inPorphyromonas gingivalis. Langmuir 2016, 32, $3024-3035$. [CrossRef]

40. Cappi, B.; Neuss, S.; Salber, J.; Telle, R.; Knüchel, R.; Fischer, H. Cytocompatibility of high strength non-oxide ceramics. J. Biomed. Mater. Res. Part A 2009, 93, 67-76. [CrossRef] [PubMed]

41. Guedes e Silva, C.C.; König, B., Jr.; Carbonari, M.J.; Yoshimoto, M.; Allegrini, S., Jr.; Bressiani, J.C. Tissue response around silicon nitride implants in rabbits. J. Biomed. Mater. Res. A 2007, 84, 337-343. [CrossRef]

42. Jahanmir, S.; Özmen, Y.; Ives, L. Water Lubrication of Silicon Nitride in Sliding. Tribol. Lett. 2004, 17, 409-417. [CrossRef]

43. Zhang, W.; Titze, M.; Cappi, B.; Wirtz, D.C.; Telle, R.; Fischer, H. Improved mechanical long-term reliability of hip resurfacing prostheses by using silicon nitride. J. Mater. Sci. Mater. Electron. 2010, 21, 3049-3057. [CrossRef]

44. Olofsson, J.; Pettersson, M.; Teuscher, N.; Heilmann, A.; Larsson, K.; Grandfield, K.; Persson, C.; Jacobson, S.; Engqvist, H. Fabrication and evaluation of SixNy coatings for total joint replacements. J. Mater. Sci. Mater. Electron. 2012, 23, 1879-1889. [CrossRef] 
45. Ely, K.S.; Khandkar, A.C.; Lakshminarayanan, R.; Hofmann, A.A. Hip Prosthesis with Monoblock Ceramic Acetabular Cup. U.S. Patent 8,133,284, 2012.

46. Lewis, G. Properties of crosslinked ultra-high-molecular-weight polyethylene. Biomaterials 2001, 22, 371-401. [CrossRef]

47. Turner, A.; Okubo, Y.; Teramura, S.; Niwa, Y.; Ibaraki, K.; Kawasaki, T.; Hamada, D.; Uetsuki, K.; Tomita, N. The antioxidant and non-antioxidant contributions of vitamin $\mathrm{E}$ in vitamin $\mathrm{E}$ blended ultra-high molecular weight polyethylene for total knee replacement. J. Mech. Behav. Biomed. Mater. 2014, 31, 21-30. [CrossRef] [PubMed]

48. Pezzotti, G. Bioceramics for Hip Joints: The Physical Chemistry Viewpoint. Materials 2014, 7, 4367-4410. [CrossRef]

49. Goodman, S.B.; Gallo, J. Periprosthetic Osteolysis: Mechanisms, Prevention and Treatment. J. Clin. Med. 2019, 8, 2091. [CrossRef]

50. Petterson, M. Silicon Nitride for Total Hip Replacement. Ph.D. Thesis, Uppsala University, Uppsala, Sweden, 2015.

51. Lal, S.; Caseley, E.A.; Hall, R.M.; Tipper, J.L. Biological Impact of Silicon Nitride for Orthopaedic Applications: Role of Particle Size, Surface Composition and Donor Variation. Sci. Rep. 2018, 8, 9109. [CrossRef]

52. Guedes e Silva, C.C.; Rodas, A.C.D.; Carvalho, F.M.S.; Higo, O.Z.; Ferreira, T.S. Silicon nitride with titania, calcia and silica additives for orthopedic applications. Proc. Appl. Ceram. 2020, 14, 63-70. [CrossRef]

53. Brydone, A.S.; Meek, D.; Maclaine, S. Bone grafting, orthopaedic biomaterials, and the clinical need for bone engineering. Proc. Inst. Mech. Eng. Part H J. Eng. Med. 2010, 224, 1329-1343. [CrossRef]

54. Ahuja, N.; Awad, K.R.; Brotto, M.; Aswath, P.B.; Varanasi, V. A comparative study on silicon nitride, titanium and polyether ether ketone on mouse pre-osteoblast cells. Med. Devices Sens. 2020. [CrossRef]

55. He, G.P.; Hirschfeld, D.A.; Cesarano III, J. Processing and mechanical properties of silicon nitride formed by robocasting aqueous slurries. Ceram. Eng. Sci. Proc. 2000, 21, 607-614.

56. Travitzky, N.; Bonet, A.; Dermeik, B.; Fey, T.; Filbert-Demut, I.; Schlier, L.; Schlordt, T.; Greil, P. Additive Manufacturing of Ceramic-Based Materials. Adv. Eng. Mater. 2014, 16, 729-754. [CrossRef]

57. Zhao, S.; Xiao, W.; Rahaman, M.N.; O’Brien, D.; Seitz-Sampson, J.W.; Bal, B.S. Robocasting of silicon nitride with controllable shape and architecture for biomedical applications. Int. J. Appl. Ceram. Technol. 2017, 14, 117-127. [CrossRef]

58. Sainz, M.A.; Serena, S.; Belmonte, M.; Miranzo, P.; Osendi, M.I. Protein adsorption and in vitro behavior of additively manufactured 3D-silicon nitride scaffolds intended for bone tissue engineering. Mater. Sci. Eng. C 2020, 115, 110734. [CrossRef] [PubMed]

59. Raza, S.M.; Khurshid, Z.; Zafar, M.S.; Najeeb, S.; Ul Yaqin, S.A. Silicon nitride (SiN): An emerging material for dental implant applications. In Dental Implants: Materials, Coatings, Surface Modifications and Interfaces with Oral Tissue; Zafar, M.S., Khurshid, Z., Khan, A.S., Najeeb, S., Sefat, F., Eds.; Series in Biomaterials; Woodhead Publ. Ltd.: Sawston, Cambridge, UK, 2020; pp. 287-299.

60. Badran, Z.; Struillou, X.; Hughes, F.J.; Soueidan, A.; Hoornaert, A.; Ide, M. Silicon Nitride (Si3N4) Implants: The Future of Dental Implantology? J. Oral Implant. 2017, 43, 240-244. [CrossRef] [PubMed]

61. Özdoğan, M.S.; Güngörmüş, M.; Çelik, A.; Topateş, G. Silicon nitride ceramic for all-ceramic dental restorations. Dent. Mater. J. 2020, 39, 1080-1086. [CrossRef] [PubMed]

62. Wananuruksawong, R.; Jinawath, S.; Padipatvuthikul, P.; Wasanapiarnpong, T. Fabrication of Silicon Nitride Dental Core Ceramics with Borosilicate Veneering material. IOP Conf. Ser. Mater. Sci. Eng. 2011, 18, 192010. [CrossRef]

63. Is silicon Nitride a Superior Biomaterial? Available online: https://www.dentalreview.news/technology/765-is-silicon-nitridea-superior-biomaterial (accessed on 22 March 2021).

64. Krajangta, N.; Sarinnaphakorn, L.; Didron, P.P.; Wasanapiarnpong, T. Development of silicon nitride ceramic for CAD/CAM restoration. Dent. Mater. J. 2020, 39, 633-638. [CrossRef]

65. Dentistry-Ceramic Materials-Amendment 1; ISO 6872: 2015/AMD 1:2018; The International Standards Organization for Standardization (ISO): Geneva, Switzerland, 2018.

66. Marin, E.; Zanocco, M.; Boschetto, F.; Santini, M.; Zhu, W.; Adachi, T.; Ohgitani, E.; McEntire, B.J.; Bal, B.S.; Pezzotti, G. Silicon nitride laser cladding: A feasible technique to improve the biological response of zirconia. Mater. Des. 2020, 191, 108649. [CrossRef]

67. Wroblewska, L.; Kitada, T.; Endo, K.; Siciliano, V.; Stillo, B.; Saito, H.; Weiss, R. Mammalian synthetic circuits with RNA binding proteins for RNA-only delivery. Nat. Biotechnol. 2015, 33, 839-841. [CrossRef]

68. Froeter, P.; Huang, Y.; Cangellaris, O.V.; Huang, W.; Dent, E.W.; Gillette, M.U.; Williams, J.C.; Li, X. Toward Intelligent Synthetic Neural Circuits: Directing and Accelerating Neuron Cell Growth by Self-Rolled-Up Silicon Nitride Microtube Array. ACS Nano 2014, 8, 11108-11117. [CrossRef]

69. Microtubes Create Cozy Space for Neurons to Grow, and Grow Fast. Available online: https://phys.org/news/2014-11microtubes-cozy-space-neurons-fast (accessed on 20 March 2012).

70. Froeter, P.J. Biocompatible Silicon Nitride Thin Films for Self-Rolled-Up Microtube Technologies: Guiding Neurons. Ph.D. Thesis, University of Illinois, Urbana-Champaign, IL, USA, 2014.

71. Froeter, P.; Yu, X.; Huang, W.; Du, F.; Li, M.; Chun, I.; Kim, S.H.; Hsia, K.J.; A Rogers, J.; Li, X. 3D hierarchical architectures based on self-rolled-up silicon nitride membranes. Nanotechnology 2013, 24, 475301. [CrossRef]

72. Ning, C.; Zhou, L.; Tan, G. Fourth-generation biomedical materials. Mater. Today 2016, 19, 2-3. [CrossRef]

73. Zanocco, M.; Marin, E.; Boschetto, F.; Adachi, T.; Yamamoto, T.; Kanamura, N.; Zhu, W.; McEntire, B.J.; Bal, B.S.; Ashida, R.; et al. Surface Functionalization of Polyethylene by Silicon Nitride Laser Cladding. Appl. Sci. 2020, 10, 2612. [CrossRef] 
74. Pezzotti, G.; Marin, E.; Adachi, T.; Lerussi, F.; Rondinella, A.; Boschetto, F.; Zhu, W.; Katajima, T.; Inada, K.; McEntire, B.J. Incorporating Si3N4 into PEEK to produce antibacterial, osteoconductive, and radiolucent spinal implants. Macromol. Biosci. 2018, 18, 1800033. [CrossRef]

75. Ishikawa, M.; Bentley, K.L.D.M.; McEntire, B.J.; Bal, B.S.; Schwarz, E.M.; Xie, C. Surface topography of silicon nitride affects antimicrobial and osseointegrative properties of tibial implants in a murine model. J. Biomed. Mater. Res. Part A 2017, 105, 3413-3421. [CrossRef] [PubMed]

76. Lehman, C.W.; Flur, R.; Kehn-Hall, K.; McEntire, B.J.; Sonny Bal, S. Silicon Nitride Inactivates SARS-CoV-2 In Vitro. bioRxiv. August 2020. Available online: https:/ / doi.org/10.1101/2020.08.29.271015 (accessed on 15 March 2021).

77. Carter, E.A.; Rayner, B.S.; McLeod, A.I.; Wu, L.E.; Marshall, C.P.; Levina, A.; Aitken, J.B.; Witting, P.K.; Lai, B.; Cai, Z.; et al. Silicon nitride as a versatile growth substrate for microspectroscopic imaging and mapping of individual cells. Mol. BioSyst. 2010, 6, 1316-1322. [CrossRef]

78. Gannot, I.; Ben-David, M. Optical fibers and waveguides for medical applications. In Biomedical Photonics Handbook, 2nd ed.; CRC Press: Boca Raton, FL, USA, 2014; pp. 229-251.

79. Hainberger, R.; Muellner, P.; Melni, E.; Mutinati, G.; Eggeling, M.; Maese-Novo, A.; Vogelbacher, F.; Kraft, J.; Koppitsch, G.; Meinhardt, G.; et al. Silicon nitride waveguide integration platform for medical diagnostic application. In Proceedings of the 2016 Progress in Electromagnetic Research Symposium, Shanghai, China, 8-11 August 2016; p. 781.

80. Rönn, J.; Zhang, W.; Autere, A.; Leroux, X.; Pakarinen, L.; Alonso-Ramos, C.; Säynätjoki, A.; Lipsanen, H.; Vivien, L.; Cassan, E.; et al. Ultra-high on-chip optical gain in erbium-based hybrid slot waveguides. Nat. Commun. 2019, 10, 432. [CrossRef] [PubMed]

81. Rank, E.A.; Sentosa, R.; Harper, D.J.; Salas, M.; Gaugutz, A.; Seyringer, D.; Nevlacsil, S.; Maese-Novo, A.; Eggeling, M.; Muellner, P.; et al. Toward optical coherence tomography on a chip: In vivo three-dimensional human retinal imaging using photonic integrated circuit-based arrayed waveguide gratings. Light. Sci. Appl. 2021, 10, 6. [CrossRef]

82. Baets, R.G. Applications of silicon photonics in life science and medicine. In Proceedings of the Emerging Applications in Silicon Photonics, Online Only, UK, 8 October 2020; p. 1157703.

83. Dhakal, A.; Subramanian, A.Z.; Wuytens, P.; Peyskens, F.; Le Thomas, N.; Baets, R. Evanescent excitation and collection of spontaneous Raman spectra using silicon nitride nanophotonic waveguides. Opt. Lett. 2014, 39, 4025-4028. [CrossRef]

84. Wuytens, P.C.; Skirtach, A.G.; Baets, R. On-chip surface-enhanced Raman spectroscopy using nanosphere-lithography patterned antennas on silicon nitride waveguides. Opt. Express 2017, 25, 12926-12934. [CrossRef]

85. Antoniou, M.; Tsunidi, D.; Petrou, P.S.; Beltsios, K.G.; Kakabakos, S.E. Functionalization of silicon oxide and silicon nitride surfaces with aminosilanes for optical biosensing applications. Med. Devices Sens. 2020, 3, e10072. [CrossRef] 